\title{
Mary H. Gibbon: teamwork of the heart.
}

Alexandra Columbus, BA

Thomas Jefferson University

Scott W. Cowan, MD

Thomas Jefferson University

Charles J. Yeo, MD

Thomas Jefferson University

Stacey A. Milan, MD

Thomas Jefferson University

Follow this and additional works at: https://jdc.jefferson.edu/gibbonsocietyprofiles

Part of the History of Science, Technology, and Medicine Commons, and the Surgery Commons Let us know how access to this document benefits you

\section{Recommended Citation}

Columbus, BA, Alexandra; Cowan, MD, Scott W.; Yeo, MD, Charles J.; and Milan, MD, Stacey A., "Mary H. Gibbon: teamwork of the heart." (2014). Department of Surgery Gibbon Society Historical Profiles. Paper 22.

https://jdc.jefferson.edu/gibbonsocietyprofiles/22

This Article is brought to you for free and open access by the Jefferson Digital Commons. The Jefferson Digital Commons is a service of Thomas Jefferson University's Center for Teaching and Learning (CTL). The Commons is a showcase for Jefferson books and journals, peer-reviewed scholarly publications, unique historical collections from the University archives, and teaching tools. The Jefferson Digital Commons allows researchers and interested readers anywhere in the world to learn about and keep up to date with Jefferson scholarship. This article has been accepted for inclusion in Department of Surgery Gibbon Society Historical Profiles by an authorized administrator of the Jefferson Digital Commons. For more information, please contact: JeffersonDigitalCommons@jefferson.edu. 


\section{Mary H. Gibbon: Teamwork of the Heart}

ALEXANDRA COLUMBUS, B.A., SCOTT W. COWAN, M.D., CHARLES J. YEO, M.D., STACEY A. MILAN, M.D.

From the Department of Surgery, Thomas Jefferson University, Jefferson Medical College, Philadelphia, Pennsylvania

$\mathrm{M}$ ARY "MALY" HopKInson Gibbon was born on September 25, 1903, to an affluent New England family who encouraged her to embrace her intelligence and to follow that by which she was intrigued. In doing this, Maly pursued work in scientific research, where she ultimately met her first husband, Dr. John "Jack" $\mathrm{H}$. Gibbon. Jack and Maly were partners in every sense of the word. Their collaboration, both within and beyond the walls of the research laboratory, made it possible for the Gibbon dream of the heart-lung machine to be realized.

In February 1930, on the campus of Boston City Hospital, a young surgeon by the name of John "Jack" H. Gibbon, Jr., was becoming accustomed to the pressures of surgical fellowship. In the laboratory of Dr. Edward Churchill, Jack worked hard to sharpen his surgical skill while simultaneously developing research hypotheses. His first objective was to investigate the relationship between pulmonary artery pressure and blood flow in animals through experimentally produced arteriovenous fistulas. Jack would not be forced to carry out the entirety of the work on his own. A technician with 3 years' experience in Dr. Churchill's laboratory, Mary "Maly" Hopkinson, was assigned to serve as Jack's research assistant (Fig. 1). ${ }^{1}$ Hence, a great partnership was formed and the history of medicine was forever changed.

Mary Hopkinson, the second of five daughters of Charles S. and Elinor Curtis Hopkinson, was born on September 25, 1903, in Manchester, Massachusetts. Both of her parents were from established New England families; Maly's father was a notable painter (Fig. 2). The family's primary home was located in Cambridge, Massachusetts, and, growing up, Maly would spend time both in the city of Boston and by the sea in Manchester. The family relished in a circle of friends distinguished in fields ranging from art, to medicine, to law. From a young age, Maly was encouraged to explore a wide variety of intellectual pursuits.

In 1923, Maly enrolled at Bryn Mawr College in the suburbs of Philadelphia. After 2 years at Bryn Mawr,

Address correspondence and reprint requests to Scott W. Cowan, M.D., Department of Surgery, Thomas Jefferson University, 1100 Walnut Street, 5th Floor, Philadelphia, PA 19107. E-mail: Scott. Cowan@jefferson.edu.
Maly studied piano in Paris, where her cousin, Francis, and her husband, the physician Dr. Frank FremontSmith, were residing. Over the course of her year in Paris, Maly found herself fascinated by Dr. FremontSmith's discussions of his medical practice. ${ }^{1}$ On her return to Boston, Maly approached Dean Edsall at Harvard and asked for medical laboratory work. In 1927, Maly was placed in the laboratory of Dr. Churchill. ${ }^{2}$

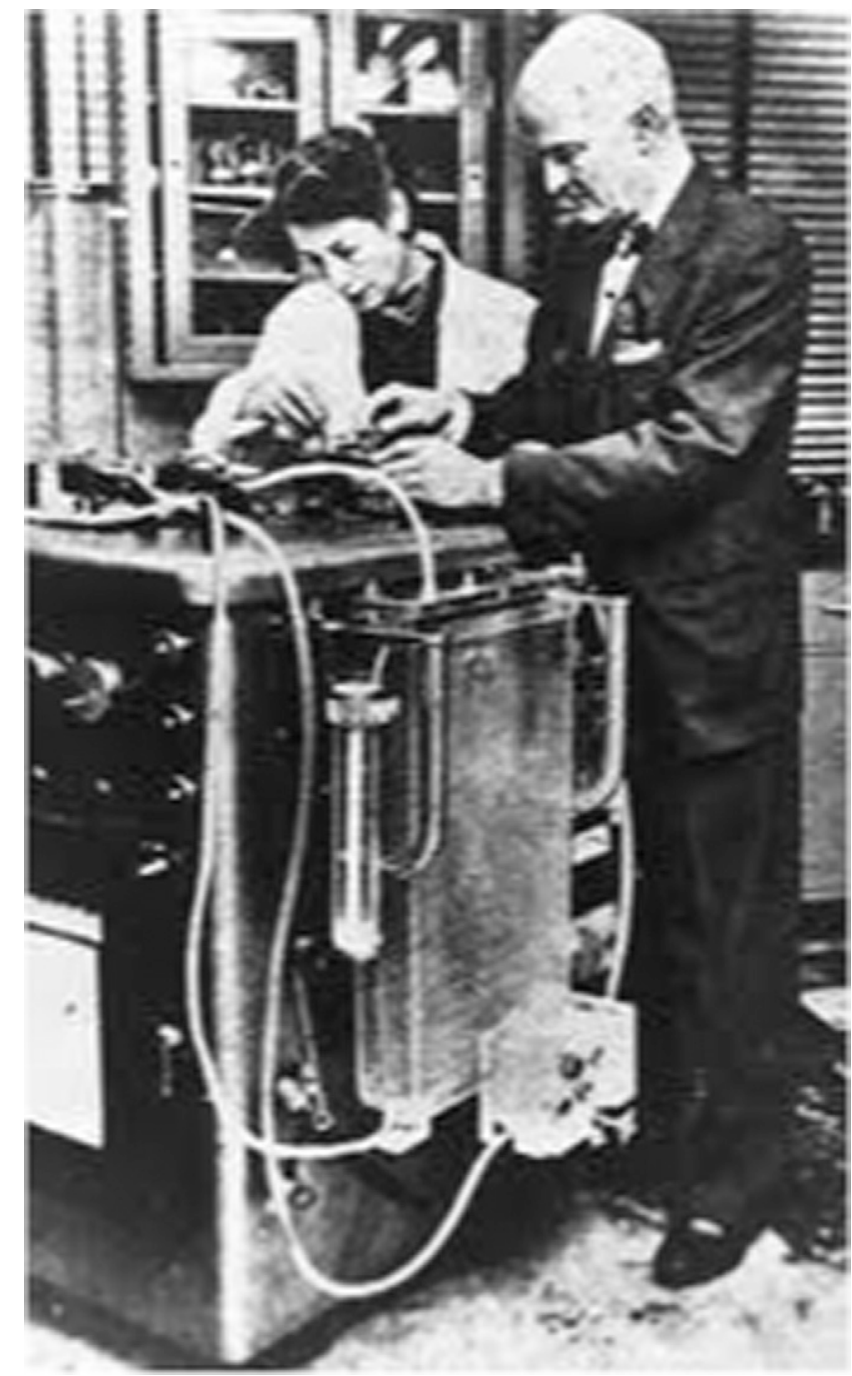

FIG. 1. Maly (left) and Dr. John Gibbon, Jr. (right) standing next to "Model II" of their heart-lung machine. Reprinted from Shumacker HB. A Dream of the Heart. Santa Barbara, CA: Fithian Press; 1999. 


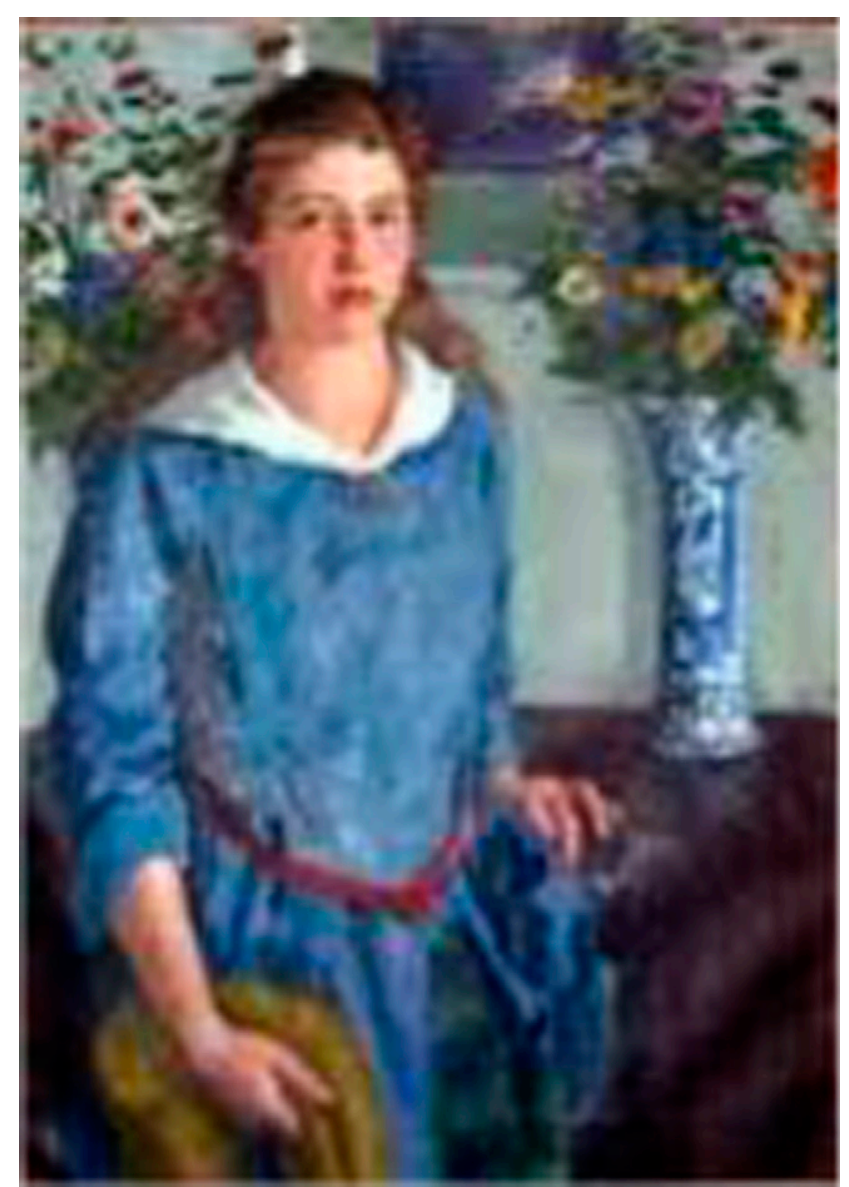

FIG. 2. A 1918 portrait of Mary Hopkinson by her father, Charles S. Hopkinson. Reprinted from CSH Virtual Gallery. Available at: www.cshgallery.org/index.html. Accessed September 4, 2010.

The relationship between Jack and Maly blossomed quickly. Maly initiated Jack into the realm of experimental surgery. During their earliest experiments together, Maly ensured procedural diligence and was instrumental to careful data collection and synthesis. ${ }^{1}$ By 1932, Jack and Maly had published 14 experiments examining the relationships between arterial pressures and cardiac output. This early work would set the stage for Jack Gibbons' idea that cardiopulmonary bypass would permit open heart surgery (Fig. 1). Jack and Maly sealed their partnership in matrimony on March 14, 1931, in Manchester. By this time, the couple was highly focused on turning Jack's idea into reality.

The years between 1931 and 1942 were remarkably productive. Although others would encourage Jack to forget his idea to focus on clinical practice, Maly relentlessly supported his efforts by balancing their growing family with long hours in the laboratory. "To do these experiments, we had to be at the laboratory bright and early, as they often continued all that day," 2 she wrote. Before Jack's deployment as a Medical Officer in World War II, the Gibbon team used a sterile technique to develop an oxygenator that would allow for viable occlusion of the feline pulmonary artery for 10 to 25 minutes at a time.

During Jack's time in the South Pacific, Maly, then settled in Philadelphia, remained active in the community and with the couple's four children, all the while researching phosgene poisoning. On Jack's return in 1945, he was named Director of Research at Jefferson Medical College and had secured a partnership with IBM Technologies. Maly remained focused beside her husband as "Model I," the first prototype of the heart-lung machine, was built. Her work aided in the evolution of "Model I" into "Model II," the machine that realized the Gibbon dream. On May 6, 1953, at Jefferson, "Model II" kept Cecelia Bavolek alive as her atrioseptal defect was repaired, making it the first successful use of an extracorporeal circuit to allow heart surgery.

Jack said that "few recognized Maly's role in his achievement." Dr. Gibbon, however, did. Jack called Maly his "greatest asset" and always acknowledged that their dialogue sparked innovation. Although conventional in her desire to maintain the home while her husband worked, Maly Gibbon differed from her peers in that she also left the home, working with her husband to change history. In this sense, she was a true renaissance woman. Her intellectual curiosity was one of her defining characteristics. In 1954, Maly received her Master's degree in social work, spending many subsequent years as a marriage counselor. After Jack's death in 1973, Maly married Dr. Lovell Thompson. She died of esophageal cancer in 1986.

The work born of the Gibbons' union is a testament to all that which teamwork is capable. Jack and Maly Gibbon gleaned inspiration from their surroundings and, in turn, inspired each other. Maly Gibbon was as logical as she was creative. ${ }^{3}$ She deeply believed in the potential of her husband's ultimately life-saving idea; it was their collective inventiveness and hard work that yielded the successful "Model II" heart-lung machine. In a time when few women worked outside of the home, Maly's intelligence and drive rendered her essential to the development of one of the great medical innovations. Maly's life underscores the profits of partnership. She helped to open doors for women who wished to excel both in the home and within the medical community.

\section{REFERENCES}

1. Shumacker HB. A Dream of the Heart. Santa Barbara, CA: Fithian Press; 1999.

2. Romaine-Davis A. John Gibbon and His Heart Lung Machine. Philadelphia, PA: University of Pennsylvania Press; 1991.

3. Burden, Nancy. The Gibbons' Interests Range from Medicine to Art. Sunday Bulletin. Philadelphia, May 10, 1964:6. 